\title{
THE FIDUCIARY DUTIES OF JOINT VENTURE PARTIES - WHEN DO THEY ARISE AND WHAT DO THEY COMPRISE?
}

\author{
Jane Knowler* and Charles Rickett**
}

\begin{abstract}
Joint Ventures are often used by parties in commercial enterprises where parties seek to achieve a common goal. One issue which is increasingly contentious is the extent to which, if any, joint venture parties owe each other fiduciary obligations. This paper refutes, as a dangerous heresy, the idea that joint venture relationships are discrete legal relationships that are inherently fiduciary in nature. The majority of self-styled "joint ventures" are, invariably, nothing more in legal terms than contracts. If parties are going to be bound by fiduciary duties, over and above the contractual duties they owe each other, this will only be so by virtue of the particular arrangement they have entered into which, on a thorough examination of the facts, is found to require each party to give unstinting loyalty to the other. Recent Australian case law bears this out.
\end{abstract}

\section{INTRODUCTION}

It is a considerable privilege to be able to write for a collection which honours a colleague and friend of many years' standing. David McLauchlan is one of the very finest common law lawyers we know. His commitment to the art of lawyering and to the teaching of that art are testified to by the reams of scholarship that have emanated from his pen (and latterly his word-processor), and by generations of his students, in both New Zealand and Australia. His friendship over the years has been a blessing to receive and experience. Forty years of teaching and writing is quite something to be proud of! May his stamina last for many more years too.

Writing during the early years of David's career, but even then more than three decades ago, Professor Ernest Weinrib, (someone one of us had the joy of introducing David to at a dinner party in Brisbane in 2007), observed that in the 250 years following the seminal decision in Keech v Sandford ${ }^{1}$ "the notion of the high standard incumbent on a fiduciary has spread from its original

* Senior Lecturer in Law, University of South Australia.

** Professor of Law, University of South Australia. 
homeland in the law of trusts and has subjected a diverse variety of entrepreneurs - directors, agents, partners, employees - to its colonizing sway". ${ }^{2}$ Today, a number of legal relationships presume the existence of fiduciary duties. These comprise the widely "accepted fiduciary relationships, such as trustee and beneficiary, agent and principal, solicitor and client, employee and employer, director and company, and partners ...". ${ }^{3}$ The fiduciary standard has been alleged to have colonised yet more contemporary commercial relationships and created a new presumptive fiduciary relationship called a "joint venture" which is governed by its own body of law. ${ }^{4}$ We endorse the view that joint ventures are neither discrete legal entities nor relationships that are inherently fiduciary in nature, and that the very idea of "joint venture law" is not only a fallacy, ${ }^{5}$ but a dangerous heresy. The majority of self-styled "joint ventures" are, invariably, nothing more in legal terms than contracts. If parties are going to be bound by fiduciary duties, over and above the contractual duties they owe each other, this will only be by virtue of the particular arrangement they have entered into which, on a thorough examination of the facts, is found to require each party to give unstinting loyalty to the other. That undertaking of loyalty justifies each party reposing trust and confidence in the other, so that one can safely conclude they are bound by fiduciary ties (which manifest themselves as fiduciary duties) to each other. This type of thorough factual examination is exemplified by the recent decision of the High Court of Australia in John Alexander's Clubs Pty Ltd $v$ White City Tennis Club Ltd. ${ }^{6}$ As a result of such examination, the Court's rather trenchant conclusion was that no fiduciary duties bound the parties and indeed no relationship existed which could properly be described on any count as a joint venture. Before we analyse this decision, we briefly outline the idea of a "joint venture" and the content of "fiduciary duties", since the ubiquitous presence of both concepts in contemporary private law discourse belies a proper understanding of their true nature.

1 (1726) SelCas Ch 61, 25 ER 223.

2 Ernest J Weinrib "The Fiduciary Obligation" (1975) 25 UTLJ 1.

3 Breen $v$ Williams (1995) 186 CLR 71 at 92 (per Dawson and Toohey JJ).

4 Chirnside v Fay [2006] NZSC 68, [2007] 1 NZLR 433. For a discussion of this decision, together with Paper Reclaim Ltd v Aotearoa International Ltd [2007] NZSC 26, [2007] 3 NZLR 169 and Amaltal Corporation Ltd v Maruha Corporation [2007] NZSC 40, [2007] 3 NZLR 192, see Jessica Palmer and Charles Rickett "Joint Ventures and Fiduciary Law" in Maree Chetwin and Phillip Joseph (eds) Joint Ventures Law (Centre for Commercial and Corporate Law Inc, University of Canterbury, 2008) 81.

5 Stephen Kós "Joint Ventures: The Collision between Contractual and Fiduciary Obligations" in Maree Chetwin and Phillip Joseph (eds) Joint Ventures Law (Centre for Commercial and Corporate Law Inc, University of Canterbury, 2008) 23.

6 [2010] HCA 19, (2010) 241 CLR 1. 


\section{JOINT VENTURES}

In a colloquial sense joint ventures are business arrangements whereby parties collaborate in a one-off enterprise "usually (but not necessarily) contributing, money, property or skill"7 in a "particular trading, commercial, mining or other financial undertaking" 8 to achieve certain outcomes which might include containing costs, limiting exposure to risk, increasing market strength, generating a product which will yield each party a separate profit or otherwise more generally sharing profits, whether equally or not. The term "joint venture" is itself "a vague one, capable of a range of applications... often used to bolster a conclusion that a fiduciary relationship exists". ${ }^{9}$ No particular business structure is mandated for joint ventures; they are implemented through any of a series of interlocking contracts, partnerships, companies, or trusts, or by way of agency or joint ownership. ${ }^{10}$ There is usually some form of contractual arrangement that governs the way the joint venture is to be carried out ${ }^{11}$ but the absence of a formal agreement is not fatal to the existence of a joint venture. ${ }^{12}$ Ultimately, whether a joint venture can (or indeed should) ever be classified as a discrete form of legal relationship which has its own particular rights and duties, distinct from a contract, partnership or any other form of established and recognised legal relationship, depends on the nature of the obligations that the joint venture parties have assumed. If such obligations or duties require the parties to act at most only with due care and/or in good faith towards each other that puts an end to further enquiry. The so-called "joint venture" is, in law, nothing other than a contract. The parties are bound by the express and implied terms of the agreement between them. If one of the parties breaches the agreement the remaining parties are left to their traditional and well-established remedies for breach of contract.

However, if an examination of the duties that the parties have assumed ${ }^{13}$ reveals that, in addition to any duties of care and/or good faith, they are mutually required to put the other's or their joint interest ahead of their own individual interest (in other words, that their duty is to act "with utmost loyalty" towards their fellow venturer/s), then their relationship will be a "joint venture" that involves fiduciary duties. The issue in that context will be to determine to which aspect of the parties' joint venture such fiduciary duties extend. To ask whether the relationship is fiduciary and

7 United Dominion Corporation Ltdv Brian Pty Ltd (1985) 157 CLR 1, at 10.

8 Ibid.

9 John Alexander's Clubs Pty Ltdv White City Tennis Club Ltd, above n 6, at [44].

10 United Dominion Corporation Ltd v Brian Pty Ltd, above n 7, at 10

11 Such contractual arrangements would typically include unit trust deeds (trust joint venture), shareholder agreements (incorporated joint venture), joint venture agreements (unincorporated joint venture), or agency or partnership agreements/deeds.

12 United Dominion Corporation Ltd v Brian Pty Ltd, above n 7; Chirnside v Fay, above n 4.

13 As manifested by the terms of any written agreement and/or by what they have said and/or done. 
then seek to ascertain the extent of the duties owed, in effect puts the cart before the horse. The analytically correct, and accordingly in our view preferable, way to proceed is to examine and evaluate the content of the duties that the parties have agreed to or undertaken. If such examination reveals that the duties compel loyalty, the parties' "relationship" inevitably assumes a fiduciary status. It is only when that conclusion is reached that the aspect over which it is claimed that the fiduciary duties extend can be examined, so as to ascertain whether or not there has been a breach and whether or not the aggrieved party is entitled to claim equitable relief. ${ }^{14}$

\section{FIDUCIARY DUTY}

The content of the fiduciary duty compels complete loyalty. Millett LJ in Bristol and West Building Society $v$ Mothew described it in the following way: 15

The distinguishing obligation of the fiduciary is loyalty. The principal is entitled to the single-minded loyalty of his fiduciary. This core liability has several facets. A fiduciary must act in good faith; he must not make a profit out of his trust; he must not place himself in a position where his duty and his interest may conflict; he may not act for his own benefit or for the benefit of a third person without the informed consent of his principal. This is not intended to be an exhaustive list, but it is sufficient to indicate the nature of fiduciary obligations. They are the defining characteristics of the fiduciary.

What is important to notice here is that a duty of loyalty is different from a duty to act in the best interests of the principal. Transactions between individuals occur in the context of a continuum of different behaviours ranging from coercion at the one end to altruism at the other. All such transactions are informed by different legal standards which are manifested in the various familiar doctrines of duties of care, unconscionable conduct, good faith and fair dealing, and fiduciary duties. As Professor Finn (as he then was) observed over twenty years ago in an important paper, all except the last mentioned standard in the list are concerned with mediating between the several interests of the parties to a relationship. ${ }^{16}$ For instance, a duty not to act unconscionably allows A to act self-interestedly provided A eschews excessive self interest at the point of transacting by not exploiting B's interests where B is in a position of vulnerability. So too a duty of good faith and fair dealing enables A to promote A's own interests provided that at the same time she has positive regard for B's interests. ${ }^{17}$ Fiduciary duties of loyalty, on the other hand, have an entirely different focus. Acting loyally towards B requires A to "act selflessly", ${ }^{18}$ and thus to eschew self-interest

14 Birtchnell v The Equity Trustees, Executors and Agency Company Ltd (1929) 42 CLR 384, at $408-410$ (per Dixon J).

15 [1998] Ch 1 at 18.

16 PD Finn "The Fiduciary Principle" in T G Youdan (ed) Equity: Fiduciaries and Trusts (Carswell, Toronto, 1989) 1.

17 Ibid, at 4

18 Ibid. 
entirely. A must act solely or exclusively in the interests of B to the exclusion of A's own interest. ${ }^{19}$ This translates in the case of both a partnership and a joint venture relationship having fiduciary incidents to the fiduciary party being obliged to subordinate his own interest to the mutual or joint interests of the association or venture rather than subordinating his interest to the best interest of his partner or fellow joint venturer. This duty of loyalty expresses itself in two central themes which have been described thus: ${ }^{20}$

The first is that which appropriates for the benefit of the person to whom the fiduciary duty is owed any benefit or gain obtained or received by the fiduciary in circumstances where there existed a conflict of personal interest and fiduciary duty or a significant possibility of such conflict: the objective is to preclude the fiduciary from being swayed by considerations of personal interest. The second is that which requires the fiduciary to account for any benefit or gain obtained or received by reason of or by use of his fiduciary position or of opportunity or knowledge resulting from it: the objective is to preclude the fiduciary from actually misusing his position for his personal advantage.

The content of the duty of loyalty as manifested in these central ideas of "precluding undisclosed conflict of duty and interest (or of duty and duty), and of prohibiting misuse of fiduciary position "21 is, in New Zealand and Australia ${ }^{22}$ in any event, widely accepted.

The same level of acceptance is however more difficult to discern when it comes to the thorn ier issue of pinpointing when and why fiduciary duties arise. Those who embark on the quest of identifying what features a relationship must exhibit so as to be the subject of fiduciary duties invariably commence their task by trotting out the well worn list of accepted "status" or nominate fiduciary relationships previously referred to. ${ }^{23}$ This they do, not only to provide a basis from which they are able to draw analogies so as to determine if fiduciary duties are present in relationships other than those nominate ones, but also in the hope that those relationships will themselves reveal some underlying and unifying factor to demonstrate when and to explain why fiduciary duties arise.

19 Gibson Motorsport Merchandise Pty Ltd v Forbes [2006] FCAFC 44, (2006) 149 FCR 569 at [12] (per Finn $\mathrm{J})$.

20 Chan v Zacharia (1984) 154 CLR 178, 198-199 (per Deane J).

21 Gibson Motorsport Merchandise Pty Ltdv Forbes, above n 19, at [12].

22 Arklow Investments Ltd v Maclean [2000] 2 NZLR 1 (PC); Breen v Williams, above n 3; Pilmer v The Duke Group Ltd (in liq) [2001] HCA 31, (2001) 207 CLR 165. See, in contrast, the position in Canada where fiduciary duties are said to be prescriptive as well as proscriptive in nature: see McInerney $v$ MacDonald (1992) 93 DLR (4th) 415 (SCC); Jacks v Davis (1982) 141 DLR (3rd) 355 (BCCA); Norberg v Wynrib (1992) 92 DLR (4th) (SCC).

23 Hospital Products Ltd v United States Surgical Corporation (1984) 156 CLR 41 at 68 (per Gibbs CJ) and at 96 (per Mason J). 
Thus, for example, Mason $\mathrm{J}$ in Hospital Products Ltd $v$ United States Surgical Corporation identified as a "critical feature" the idea of an "undertaking":24

The critical feature is that the fiduciary undertakes or agrees to act for or on behalf of or in the interests of another person in the exercise of a power or discretion which will affect the interests of that other person in a legal or practical sense.

Other courts have preferred different factors. In deciding that fiduciary duties are owed by one party to another, such duties have been said to be grounded in trust and confidence, ${ }^{25}$ vulnerability, ${ }^{26}$ inequality of bargaining power ${ }^{27}$ and reasonable expectations. ${ }^{28}$ The importunate use of such language has resulted in "abracadabra law"29 that threatens to "overwhelm" rather than to "illuminate". ${ }^{30}$ The recent trio of decisions in the New South Wales Supreme Court and Court of Appeal and the High Court of Australia in John Alexander's Clubs Pty Ltd $v$ White City Tennis Club $L t d^{31}$ attests to this trend.

\section{JOHN ALEXANDER'S CLUBS PTY LTD V WHITE CITY TENNIS CLUB LTD}

\section{A The Facts}

John Alexander's Clubs Pty Ltd ("JACS") was a company that developed sporting facilities for use by clubs. In late 2004 it became involved in the sale and purchase of a 4.5 hectare property in Paddington, Sydney owned by Tennis NSW, on which stood tennis courts, centre court stands and a car park ("the White City Land"). From 1948, White City Tennis Club ("the Club") had, through a series of leases and licences, used part of this land for its sporting activities. At the time of the events that later resulted in the litigation, the Club leased part of the Northern Stand building on the White City Land for use as its clubhouse. This lease was due to expire in 2020. It also had an annual

24 Ibid, at 96.

25 Day v Mead [1987] 2 NZLR 443 (CA) at 459-460 (per Somers J).

26 Hospital Products Ltd v United States Surgical Corporation, above n 23, at 142 (per Dawson J); Lac Minerals Ltd v International Corona Resources Ltd (1989) 61 DLR (4th) 14

27 Hospital Products Ltd v United States Surgical Corporation, above n 23, at 70 (per Gibbs CJ).

28 Lac Minerals Ltd v International Corona Resources Ltd, above n 26, at 29 (per La Forest J); Liggett v Kensington [1993] 1 NZLR 257 (PC).

29 Lord Neuberger of Abbotsbury "The Stuffing of Minerva's Owl? Taxonomy and Taxidermy in Equity" (2009) 68 CLJ 537 at 541.

30 PD Finn, above $\mathrm{n} 16$, at 2

31 White City Tennis Club Ltd v John Alexander's Clubs Pty Ltd [2008] NSWSC 1225; White City Tennis Club Ltd v John Alexander's Clubs Pty Ltd [2009] NSWCA 114, (2009) 261 ALR 86; John Alexander's Clubs Pty Ltd $v$ White City Tennis Club Ltd, above n 6. 
licence to use designated tennis courts. In 2005, Tennis NSW decided to sell the White City Land by tender closing on 15 April 2005. On 28 February, the Club and JACS had entered into a memorandum of understanding ("the MOU"). The MOU was to the effect that JACS was negotiating for the purchase of, or for an option to purchase, the whole or part of the White City Land by a company, White City Holdings ("WCH") that JACS was yet to incorporate. Existing members of the Club, together with members of the public, would be able to subscribe as "Foundation Members" for shares in WCH. Under Clause 3.7.1 of the MOU, JACS promised that if it succeeded in obtaining an option to purchase it would exercise that option on behalf of $\mathrm{WCH}$, upon WCH simultaneously leasing the land back to a JACS-related entity ("JAWCC") for 99 years and entering into an operating agreement for the running of the new club. If JACS failed or was unable to exercise this option, then JACS "promised to seek to procure a further option exercisable by the Club". ${ }^{32}$

On 10 May 2005, Tennis NSW sold the land to a third party, SGS. The Club and JACS negotiated with SGS and a further interested party to exercise the options set out in the MOU. All four parties entered into consecutive agreements culminating in the Third White City Agreement ("the Third Agreement"). Clause 8(a) of the Third Agreement granted JACS or its nominee an option, exercisable before 30 June 2007, to purchase part of the White City Land ("the Option Land") for $\$ 6.73$ million payable solely by JACS, failing which, under clause $8($ b), the Club would have, until 30 September 2007, the option to purchase the Option Land at the same price. The Club also obtained a lease of part of the Option Land which was to last until 30 September 2007 but the parties agreed that this would terminate earlier if either JACS or the Club exercised the option to buy. Finally, as part of the agreement, the Club relinquished the existing lease of its clubhouse which otherwise would have expired only in 2020. Clause 8 was not hedged with the same qualifications as in the MOU. It "did not compel JACS to exercise the option on behalf of WCH and did not refer to any grant to JAWCC of a 99 year lease or to entry into an operating agreement". ${ }^{33}$ Clauses 42 and 43 of the Third Agreement made reference back to the MOU. The former expressly acknowledged that the MOU continued according to its terms and that the Club and JACS would each perform their obligations under the Third Agreement in accordance with the MOU. The latter provided that, to the extent that there was any inconsistency between the Third Agreement and any other agreement between any of the parties, the former would prevail, unless specifically stated otherwise. $^{34}$

The relationship between the Club and JACS broke down, and in early April 2006 JACS served a notice of termination on the Club alleging that the Club had repudiated the MOU. JACS then

\footnotetext{
32 John Alexander's Clubs Pty Ltd v White City Tennis Club Ltd, above n 6, at [14].

33 Ibid, at [21].

34 Ibid, at [23]-[24].
} 
proceeded to exercise the clause 8 option through its nominee, Poplar Holdings Pty Ltd ("Poplar"). The Club sued JACS and contended that pursuant to the exercise of the option in clause 8(a) JACS owed it a fiduciary duty to hold the land on its behalf and that JACS had breached this duty by exercising the option through Poplar. This breach of fiduciary duty, the Club alleged, had caused it to lose the opportunity it had had to acquire the Option Land. It claimed a constructive trust over the Option Land subject to its paying Poplar \$6.73 million, being the purchase price.

\section{$B$ The Decision in the Lower Courts}

Young CJ in Equity, as he then was, dismissed the claim at first instance. ${ }^{35}$ Holding that "the Club was not affected by any special vulnerability, it had not relied on JACS to protect its interests, those running it were experienced in business and advised by independent solicitors, and it had equality of bargaining power with JACS",36 he concluded there was no fiduciary duty owed.

The New South Wales Court of Appeal allowed the Club's appeal ${ }^{37}$ by declaring that the Club was the beneficiary of a constructive trust imposed on Poplar/JACS for unconscionable behaviour, and, although not necessary for its conclusion, stating that there was a fiduciary relationship between JACS and the Club. ${ }^{38}$

\section{The Decision in the High Court of Australia}

The High Court disagreed with the Court of Appeal. As one commentator has observed, the Court's preliminary remarks about the nature of the Club's claims provided signposts as to the decision the Court was going to reach. ${ }^{39}$ In a unanimous ${ }^{40}$ judgment, the Court characterised as "striking" both the fact that the Club's claims were entirely non-contractual and that it was seeking an all-or-nothing claim of a constructive trust over the Option Land held by Poplar, despite the fact that early on in the piece it knew about and so could have sought a prohibitory injunction forbidding JACS from acquiring the land for Poplar. ${ }^{41}$ Their Honours abjured the fact that the Club was offering to pay Poplar only the price Poplar had paid for the Option Land and not offering to compensate Poplar for the loss of its use of money and/or disbursements. The Club's lack of regard

35 White City Tennis Club Ltd v John Alexander's Clubs Pty Ltd, above n 31.

36 John Alexander's Clubs Pty Ltd v White City Tennis Club Ltd, above n 6, at [30].

37 White City Tennis Club Ltd v John Alexander's Clubs Pty Ltd, above n 31, at [63]-[102].

38 Ibid, at [83]-[91].

39 See Robert Flannigan "Collateral Contracting Implicitly May Vary Fiduciary Accountability" (2010) 126 LQR 496.

40 French CJ, Gummow, Hayne, Heydon and Kiefel JJ.

41 John Alexander's Clubs Pty Ltd v White City Tennis Club Ltd, above n 6, at [37]-[38]. 
for subsequently intervening third party interests of which it had notice was concerning. ${ }^{42}$ The Court of Appeal's use of "joint venture" terminology in the three opening paragraphs of its judgment in the face of an express "disavowal of the existence of any joint venture by the Club at trial", ${ }^{43}$ as well as the express provision in clause 7.1 in the MOU that "nothing in the MOU (should) be taken to constitute the Parties as partners or as joint venturers for any purpose whatsoever" 44 raised, so the High Court said, "a doubt about the Court of Appeal's reasoning". ${ }^{45}$

The High Court then proceeded to review the Court of Appeal's construction of clause 3.7 of the MOU and clause 8 of the Third Agreement. It characterised as "flawed" the Court of Appeal's reasoning that the various agreements entered into by the parties were "a unity taking shape entirely from the MOU" so that "if JACS had exercised the option purportedly on its own behalf and for its own benefit while the MOU was on foot, JACS would have been in breach of ... cl 3.7.1".46 Instead, the High Court found that JACS's obligation in clause 3.7 of the MOU to exercise the option on behalf of WCH had been conditional on the grant of a 99 year lease and entry into an operating agreement with the related JACS entity (JAWCC). But, as it transpired, before this could even have occurred the parties had altered the content of the option clause in three subsequent agreements, each one differing in effect from its predecessor. None of these later agreements had required JACS to exercise the option on behalf of WCH. Instead, each one had given the option to JACS in its own right. All three agreements had required the Club to surrender its rights in relation to the White City Land but, whereas the first two agreements had granted JACS a two year lease over the Option Land, the Third Agreement had given the lease to the Club alone. The first two agreements had not provided for the continuation of the MOU. The Third Agreement, by contrast, had stated that the MOU was to continue except where inconsistent with that agreement. ${ }^{47}$ In the High Court's view, there were quite clearly inconsistent provisions as regards the option clause. This meant that the option to purchase in "[c]lause 3.7 had to give way, and cl 8 had to prevail". ${ }^{48}$ True it

42 Ibid.

43 Ibid, at [44].

44 Ibid, at [42].

45 Ibid. This reasoning seems rather thin. The exclusion of the existence of a joint venture and hence of fiduciary duties - that alone being the purpose for which the joint venture's existence was alleged - solely on the basis of the parties' own expressed intention can certainly only ever be one consideration amongst many to be taken into account in the thorough examination otherwise required. It cannot suffice in and of itself to exclude fiduciary duties since that would be to honour form over substance in deciding a matter where substance must be the central concern. The Court's reference to "doubt' might of course indicate its awareness of this framework, but that is not clear.

46 Ibid, at [51]-[52].

47 Ibid, at [52]-[55].

48 Ibid, at [50]. 
was that the MOU did not expressly permit Poplar to exercise the option. But this was not in the High Court's view sufficient for the Club to claim equitable fraud, unconscionable conduct or breach of fiduciary duty by JACS. ${ }^{49}$ The option contemplated by the MOU was a conditional one only. And the two conditions were never carried out. The clause setting out that option was replaced by something quite different in form in the Third Agreement. The Club had freely agreed to the Third Agreement and to those preceding it. It did not allege that its consent had been procured by "mistake, misrepresentation, undue influence, duress, overbearing of the will, unequal bargaining power or concealment. Those who decided the Club should consent were experienced in business and legally advised." ${ }^{50}$ There was, in the High Court's view, no compelling basis for imposing a constructive trust in the Club's favour over the Option Land.

So, if there was no equitable fraud or unconscionable bargain, did JACS owe the club fiduciary duties? The New South Wales Court of Appeal had answered this question in the affirmative. It held that when the Club agreed to clause 3.7.1 in the MOU it had placed itself in the hands of JACS and had trusted and relied on JACS to exercise any purchase option (including the option in cl 8 of the Third Agreement) on behalf of WCH, as it had said it would do. The Club was vulnerable to JACS. If JACS were to fail to honour its commitment to act for the Club this would preclude the Club from having the opportunity to acquire a valuable property right and to continue conducting the sporting activities it had been conducting for the previous 55 years on the White City Land. ${ }^{51}$

The High Court rejected this line of reasoning which it said was based on the "twin ideas of vulnerability and reliance" ${ }^{52}$ It held that the question as to the existence of fiduciary duties could only be answered in the context of the contracts the Club had entered into with the various parties. ${ }^{53}$ Although the MOU had obliged JACS to obtain an option and deal with it in a certain way, all three subsequent White City agreements had given the purchase option to JACS unconditionally. The Club had freely consented to this; hence Young CJ in Equity's strong impression "that instead of there being an arrangement whereby the [Club] entrusted JACS to act on its behalf, the [Club] was going to act on its own behalf unless JACS complied with its demand". ${ }^{4}$ If the Club was vulnerable, it was only in the sense that every party to a contract is vulnerable to breach of the other party's duties by that other party. ${ }^{55}$ The unconditional nature of the later options acquired by JACS,

\footnotetext{
49 Ibid, at [56].

50 Ibid.

51 Ibid, at [80].

52 Ibid, at [81].

53 Ibid, at [82].

54 Ibid.

55 Ibid, at [83].
} 
to which the Club had consented, fundamentally altered the nature of any fiduciary obligations that JACS might have owed to the Club under the MOU. The Club could have "bargained for more precision in Clause 8, using its ability to refuse to agree to surrender the Lease". ${ }^{56}$ It had not done so. It had neither relied on JACS's representations, nor been overborne by JACS's greater strength. It had not depended on JACS to carry out dealings of which it was ignorant, nor had it trusted JACS to do anything. ${ }^{57}$ This analysis led the High Court to conclude that "[w]hat JACS and the Club did in relation to the Third White City Agreement and the exercise of JACS's option under cl 8(a), they did consulting their own interests, with knowledge of what the other was doing". ${ }^{58}$ Any vulnerability or reliance was grounded in contract only. If the Club chose not to make use of the "ample array of contractual remedies to protect itself" that was its choice. It might well have experienced difficulty, as a social club, in giving an undertaking as to damages; its members might well have wanted to continue using the facilities rather than being awarded monetary compensation; there might have been problems suing companies like JACS or Poplar which had no assets to meet any judgment made against them. All of these considerations, however, "did not justify converting the contractual relationship between JACS and the Club into a fiduciary relationship". ${ }^{59}$

The High Court's analysis can be (and has been) questioned. ${ }^{60}$ The Club itself argued in the High Court (although not in the Court of Appeal) that clauses 3.7.1, 8 and 42 could be interpreted differently. Although its submission was given short shrift, there is a plausible argument that there was no inconsistency between the option in clause 3.7.1 of the MOU and that in clause 8 of the Third Agreement. ${ }^{61}$ Clause 42 of the Third Agreement contained a provision that the MOU would continue in accordance with its terms and that the Club and JACS would carry out their respective obligations under the Third Agreement in accordance with the MOU. Clause 3.7.1 of the MOU required JACS to acquire the land on behalf of WHC. Even if the later $\mathrm{cl} 8$ in the Third Agreement gave the option to acquire the land to JACS alone, that was a matter between the grantor of the option and JACS - it said nothing about the relationship between JACS and the Club which was still governed by the MOU. Added to this, of course, is the fact that the two component parts of the condition - the 99 year lease and operating agreement - were exclusively in JACS's control. JACS claimed "repudiation" of the MOU by the Club. This self-serving claim (which might well be found not to have been justified in a subsequent trial) immediately absolved JACS from its responsibilities to set up the two entities. JACS would then of course be in breach of its contractual obligations, but

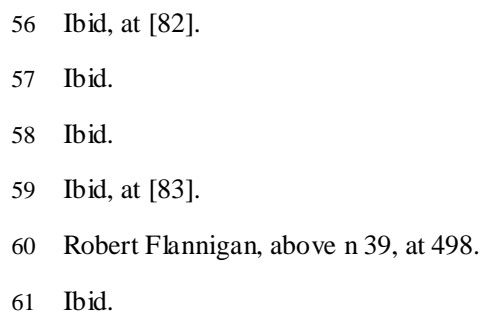


were it to be in breach of its concurrent fiduciary duties the possibility of the Club's getting the land back by means of a proprietary remedy was much stronger. Given this, was the High Court really justified in finding that any original fiduciary duties were impliedly converted into mere contractual ones by dint of the later arrangements?

In one sense, the answer does not matter. What is important in all this, to reiterate the point we have made above, is that what the High Court did was to interpret the terms of the various contracts in order to ascertain the nature of the duties the parties had themselves assumed. Professor Flannigan's argument is, in effect, one for a different construction of the various contracts which, if adopted, might have led the Court to hold that fiduciary duties were owed and had not been extinguished. Perhaps the Club had this interpretation in mind in framing its argument, which might explain why it was so convinced of the correctness of its view that it was prepared to promote its "all-or-nothing" claim in the first place. This process is, however, no different from that adopted by courts in those other cases where fiduciary duties have been found to exist, and where the description "joint venture" has been applied to the parties' arrangement.

The question of fiduciary duties could have ended at this point. However, it did not. In the High Court the Club, with leave of the Court, had advanced a further argument in relation to its fiduciary relationship case, relying on Mason J's widely accepted "undertaking" test (as described above) for establishing the existence of fiduciary duties. The Club contended that "the MOU was an undertaking by JACS to acquire property on the Club's behalf and hold it for interested parties". ${ }^{62}$ The High Court took the opportunity to make some comments about fiduciary duties in general (perhaps in an attempt to quell increasing resort to the abracadabra-like ritual incantation of the term "joint venture" and the lure of fiduciary law as a means to access equity's extensive and powerful remedies when there is no sound doctrinal basis to make any such claim). ${ }^{63}$ Relying on the extrajudicial writings of the late Justice Lehane, the High Court said that the phrases "for" or "on behalf of" which signify an undertaking must be strictly construed "lest the criterion they formulate become circular". ${ }^{64}$

In every relationship that attracts fiduciary duties the purpose of the undertaking is gleaned from the terms of the arrangement between the parties understood in the context of its execution (to wit, the principal giving the fiduciary permission to deal in some way with the beneficiary's protected interest - be it property or opportunity - and the fiduciary undertaking to hold and use that protected interest exclusively for the principal). Thus, it is relatively easy to construe the undertaking given by

62 John Alexander's Clubs Pty Ltdv White City Tennis Club Ltd, above n 6, at [85].

63 PD Finn, above n 16, at 56.

64 John Alexander's Clubs Pty Ltd v White City Tennis Club Ltd, above n 6, at [88] citing John Lehane "Fiduciaries in a Commercial Context" in PD Finn (ed) Essays in Equity (Law Book Company, Sydney, 1985) 95 at 101. 
a trustee administering a trust estate, or by a director participating in the control and management of a company as fiduciary in nature ${ }^{65}$ (these being classical status-based fiduciaries). Similarly construed undertakings limited by their representative nature have also arisen as a matter of fact in the particular circumstances of cases (these being fact-based fiduciaries). If a person (Y) wants to bring herself within the class of fact-based beneficiaries of fiduciary duties (because she is not in a partnership, trust or other status-based relationship with $\mathrm{X}$ ) then she must unequivocally demonstrate that $\mathrm{X}$ 's offer to enter into a contract in a deal that will apparently benefit $\mathrm{Y}$ as well as $\mathrm{X}$ has become an undertaking to act for or on behalf of $\mathrm{Y}$ and therefore to act, in relation to that contract, solely in the interests of Y. ${ }^{66}$ If $\mathrm{Y}$ cannot establish the existence of such an undertaking by $\mathrm{X}$, then the relationship, although definitely contractual, will not attract fiduciary duties. In addition, it should now be obvious that those who suggest that a contractual relationship does not attract fiduciary duties when and because it is commercial in nature are barking up the wrong tree. Such relationships fail to attract fact-based fiduciary duties because they fail to comply with the criteria necessary to establish the existence of fiduciary duties. ${ }^{67}$ They do not fail to do so simply because they are commercial contractual relationships; their commercial nature does not give them immunity from fiduciary regulation. Quite the contrary, as is evidenced by the existence of countless "commercial" fiduciary relationships such as, for example, partnerships, agency arrangements, and superannuation trusts. But, importantly, where these commercial fiduciary relationships are creations of contract, then any fiduciary duties parties have assumed must accommodate themselves to the terms of the contract so as not to alter the contract's true scope and distort the matrix within which the parties themselves intended to operate. ${ }^{68}$ The express terms of the agreements governed the relationship between the Club and JACS. The Club "eschewed any attempt to imply a term into the MOU to the effect of the fiduciary obligation for which it contended". 69

An undertaking by a party giving rise to fiduciary duties is thus coupled with an entrusting to that party by the first party of the latter's property or opportunity. In his dissent in Hospital Products, Mason $\mathbf{J}$ found that the limited fiduciary duty in relation to product goodwill that HPI owed to USSC flowed from the fact that USSC had "entrusted the protection, promotion and custodianship of its product goodwill in the Australian market"70 to HPI, which HPI had then undertaken to safeguard for USSC solely. USSC was on the other side of the world. It lacked the capacity to control what was happening to its product goodwill in Australia. HPI was the only

65 Ibid.

66 Ibid, at [89].

67 Ibid, at [90].

68 Hospital Products Ltd v United States Surgical Corporation, above n 23, at 97 (per Mason J).

69 John Alexander's Clubs Pty Ltd v White City Tennis Club Ltd, above n 6, at [92].

70 Ibid, at [93]. 
person in contact with the Australian market. HPI had every opportunity to prefer its own interest and to subordinate USSC's interest, but its fiduciary duty to USSC for the protection of USSC's Australian product goodwill demanded the exact opposite. ${ }^{71}$ There were countless ways, alluded to by Mason J, in which Blackman as the alter ego of HPI could operate opportunistically: he could get to know customers as distributor rather than as competitor; he could surreptitiously start manufacturing his own products; he could obtain finance from USSC and other sources; he could reduce the supply of USSC's products in Australia and replace them with his own and then supply his own products to customers who might well believe that he was acting with USSC's authority. ${ }^{72}$

But, as the High Court was quick to point out, none of these considerations was relevant with regard to the relationship between the Club and JACS. The Club was in constant contact with JACS as well as with other parties interested in the White City Land. The Club had the ability to find out what was happening and to protect its own interests. The relevant location was a small part of Sydney. "Even if JACS was in a position to deal secretly [with the other parties] it was not alleged to have done so". ${ }^{73}$ The Club had not entrusted to JACS any property or opportunity which could be abused, ${ }^{74}$ and there was no undertaking by JACS to the Club.

In the final analysis, the overwhelming reason for the Club's failure in the High Court was because that Court attached greater weight to what it viewed as the very different nature of clause 8(a) in the Third Agreement from clause 3.7.1 in the MOU. It was because of this that JACS was held not to owe fiduciary duties to the Club. There was no reference in cl 8 to granting the option for or on behalf of anyone other than JACS itself. The parties themselves had by their subsequent contracts extinguished any fiduciary duties that might have arisen by virtue of the MOU. To have found that a fiduciary duty was owed by JACS to the Club to acquire the Option Land solely for the Club, and that JACS had breached this duty by acquiring the Land for Poplar, and then to have determined that a constructive trust should be imposed on Poplar to hold the Land for the Club would have been to deny justice by invoking a "strained application of equitable ideas". ${ }^{75}$ The observation by Judge Learned Hand that "in commercial transactions it does not in the end promote justice to seek strained interpretations in aid of those who do not protect themselves" was given a hearty endorsement by the High Court bench who believed that the "Club's defence of the orders in the Court of Appeal created an unacceptable amount of strain of those kinds". ${ }^{76}$

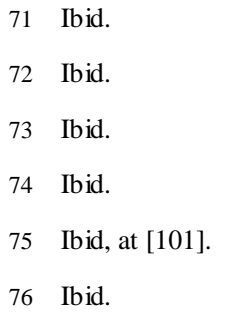




\section{$V$ JOHN ALEXANDER'S CLUBS PTY LTD V WHITE CITY TENNIS CLUB LTD - FIDUCIARY DUTIES IN JOINT VENTURE ARRANGEMENTS}

What does this recent exposition of fiduciary principles from the High Court reveal about the existence of fiduciary duties in joint venture arrangements? In our view, it confirms the position we outlined in the opening part of this paper. The relationship in question will require detailed examination to ascertain exactly what duties the parties have actually taken upon themselves. It is not good enough, as the High Court so pithily put it, simply to label an enterprise as a joint venture in order to elicit a conclusion that fiduciary duties are owed between the parties. Of course, that very statement belies the proper nature of what we might term "real" or "true" joint ventures. If an examination of the duties undertaken reveals that loyalty is required, then the enterprise might well ex post be labelled a joint venture in which the parties will owe each other fiduciary duties. But such terminology admits confusion and leads to the unthinking labelling of relationships as "joint ventures" as if there were some magic consequence associated with the term - which is nothing more than abracadabra law. We would be much better off finding some other term for these relationships - such as "single instance partnership" or "partnership for a sole purpose" which would then allow the term "joint venture" to be employed in a wider commercial context without immediately muddying well established principles of equity. In the final analysis, "joint venture" appears presently to be no more than a ragbag term for a transactional relationship where a court has determined that the parties owe each other fiduciary duties.

\section{CONCLUSION}

Simply calling a relationship a "joint venture" is, in the end, unhelpful. In particular, "ascribing the label 'joint venture' to a business relationship between two or more parties does not of itself render that relationship fiduciary for some or all of its purposes". ${ }^{77}$ The fiduciary nature of the venture depends instead upon the particular vehicle the parties choose to adopt to carry out the joint venture and the terms of the underlying agreement between them, as the High Court of Australia in fact made so clear 25 years ago, not long after Professor Weinrib made the observation which we noted at the beginning of this paper and in the earlier part of the career of the outstanding contract scholar whom we seek to honour in this volume. In a passage which would be music to the ears of perhaps the foremost contemporary scholar writing on matters of contractual interpretation, the unanimous bench of the High Court in United Dominion Corporation Ltd v Brian Pty Ltd stated: ${ }^{78}$

One would need a more confined and precise notion of what constitutes a "joint venture" than that which the term bears as a matter of ordinary language before it could be said by way of general proposition that the relationship between joint venturers is necessarily a fiduciary one ... The most that can be said is

77 Gibson Motorsport Merchandise Pty Ltd v Forbes, above n 19, at [2] (per Finn J).

78 Above n 7, at 10-11. 
that whether or not the relationship between joint venturers is fiduciary will depend upon the form which the particular joint venture takes and upon the content of the obligations which the parties to it have undertaken.

The position in New Zealand is, however, in a rather more confused state. In Chirnside v Fay ${ }^{79}$ the Supreme Court appeared to accept that joint ventures are inherently fiduciary on the basis that they are analogous to a partnership which is of course an established fiduciary relationship. ${ }^{80} \mathrm{In}$ Tipping J's view, the common feature justifying fiduciary duties in any relationship was the entitlement or legitimate expectation of one party (the beneficiary) to repose trust and confidence in the other (the fiduciary). ${ }^{81}$ On this view, a fiduciary obligation need not, therefore, be voluntarily assumed by the fiduciary. Rather, it should be understood as one that arises by legal imposition. This supposes that the consensual undertaking of fiduciary duties is not their essential requirement; ${ }^{82}$ it is merely but one justification for the imposition of the duties. The issue of what circumstances will provide a legitimate justification for the reposing of trust and confidence appears to be a matter for analogising novel fact situations to existing accepted fiduciary relationships and to case law. For example, in Chirnside itself, the similarities between the relationship of the two parties' relationship and a traditional partnership supported a finding that Fay was entitled to repose trust and confidence in Chirnside such that Chirnside became subject to fiduciary duties (in the same way that partners are). Elias CJ, with whom Keith $\mathrm{J}$ concurred on this point, characterised the joint venture with a view to sharing profit as inherently fiduciary, given that it was "indistinguishable from a single transaction partnership". ${ }^{83}$

On this reading of Chirnside, it thus appears to have been settled for New Zealand that a joint venture is deemed a fiduciary relationship by law, given its similarities to a partnership, in that it involves at least two parties undertaking a joint project on the understanding that profits will be divided among them - thus necessarily giving rise to legitimate expectations of loyalty being due from each to the other. In two subsequent cases, ${ }^{84}$ the Supreme Court has, however, sought to refine and narrow the meaning of joint venture, so that the potential for a fiduciary obligation to arise

79 Above $\mathrm{n} 4$.

80 Ibid, at [14], [74], [80] and [90]

81 Ibid, at [80].

82 Although in our view the traditional status-based fiduciary relationships are best analysed in terms of undertaking.

83 Chirnside v Fay, above n 4, at [14].

84 Paper Reclaim Ltd v Aotearoa International Ltd, above n 4 and Amaltal Corporation Ltd v Maruha Corporation, above $\mathrm{n} 4$. 
automatically is also accordingly reduced, leaving the law somewhat less certain than it appeared to be immediately after Chirnside. ${ }^{85}$

The implications for wider fiduciary law of this area and the recognition of fiduciary duties and application of equitable remedies in joint venture contexts remain therefore unfortunately somewhat unclear and incoherent. It is surely incumbent upon the superior courts to provide at the next opportunity a clear and conceptually sound analysis of the issues discussed in this paper. As a first step, the notions that joint ventures are not only legally definable as stand-alone legal institutions but also automatically give rise to status-based fiduciary duties should be knocked on the head once and for all. To some degree, the High Court of Australia in the John Alexander's Clubs case has gone some way to doing just that, but regrettably the language used therein, and certainly the actual process undertaken to resolve the issue before the Court, do not provide the level of clarity and certainty which the issue requires from a supreme appellate court. In the meantime, it is respectfully suggested that more can usefully be gleaned from the judgment of Finn $\mathrm{J}$ in Gibson Motorsport Merchandise Pty Ltd $v$ Forbes. ${ }^{86}$ This judgment deserves to be more widely known. Perhaps it will take a place at the forefront of the efforts in Australia to answer the question we set ourselves as the title of this paper: the fiduciary duties of joint venture parties - when do they arise and what do they comprise? The judgment will repay careful analysis in New Zealand also.

85 See the further analysis of these two decisions by Jessica Palmer and Charles Rickett, above $\mathrm{n} 4$, at 81 .

86 Above n 19 
(2011) 42 VUWLR 